\title{
Tribute to Theodor Kocher: Far Beyond an Anatomical Reference
}

\section{Homenagem a Theodor Kocher: Muito além de uma referência anatômica}

\author{
Angelo L. Maset ${ }^{1}{ }^{10}$ Dionei Freitas de Morais ${ }^{1}$ Sérgio Ivo Calzolari ${ }^{1}$ \\ ${ }^{1}$ Department of Neurological Sciences, Fundação Faculdade Regional \\ de Medicina de São José do Rio Preto(FUNFARME), Hospital de Base, \\ São José do Rio Preto, SP, Brasil \\ Address for correspondence Angelo Luiz Maset, MD, Av Carlos de \\ Arnaldo Silva 360, Village Sta Helena, Sao Jose do Rio Preto - SP, \\ 15091-610, Brasil (e-mail: maset@terra.com.br).
}

Arq Bras Neurocir 2020;39(3):192-196.

\begin{abstract}
Keywords

- history of Medicine

- history of the twentieth century

- surgeons

- historical Aspects of NLM Neurosurgery

\section{Resumo}

\section{Palavras-chave}

- história da Medicina

- história do século XX

- cirurgiões

- aspectos históricos da Neurocirurgia

We know Kocher's name as an anatomical reference in neurosurgery. In fact, Theodor Kocher was a Swiss general surgeon, and his contributions were such that Kocher was honored in 1909 with the Nobel Prize in Medicine and Physiology, and he was the first surgeon to receive this honor. Kocher participated in the initial scientific phase of medicine, living with names that are in history, as well as him; Langenbeck and Virchow, Lucke, Billroth, Horsley, Lister, Halstedt, Pasteur, Osler, Lawson Tait, Verneuil, and a long list and other icons of the time. The present account rescues the many important facets and contributions of the Swiss surgeon Theodor Kocher, and his relationship with several of them. Kocher's memory, surgical instruments and literary production are preserved in a small wing of the University of Bern. The present article highlights how intense Kocher's dedication to the medical field was.

Conhecemos o nome de Kocher como um referencial anatômico em neurocirurgia. Na verdade, Theodor Kocher foi um cirurgião geral suíço, e suas contribuições foram tantas que Kocher foi honrado em 1909 com o Prêmio Nobel de Medicina e Fisiologia, sendo o primeiro médico a deter esta honraria. Kocher participou da fase científica inicial da Medicina, convivendo com nomes que ficaram na história, assim como ele; Langenbeck e Virchow, Lucke, Billroth, Horsley, Lister, Halstedt, Pasteur, Osler, Lawson Tait, Verneuil, e uma longa lista e outros ícones da época. O presente relato resgata as várias e importantes facetas e contribuições do cirurgião suíço Theodor Kocher, e a sua relação com vários deles. A memória de Kocher, seus instrumentos cirúrgicos e produção literária estão preservados em uma pequena ala da Universidade de Berna. O presente artigo evidencia quão intensa foi a dedicação de Kocher à Medicina.
\end{abstract}

\section{Introduction}

The year of 2017 celebrated 100 years of the death of Theodor Kocher. Time is relentless, and historical events often interfere with due recognition to individuals who extrapolate their time.
Kocher was born in Bern, Switzerland, on August 25, 1841, and at the age of 4 years old attended school, accompanying his brother a year older. At the age of 17 , he was already enrolled at the University of Bern, and developed in this period great skills and anatomical knowledge, which made received

December 5, 2019

accepted

April 22, 2020
DOI https://doi.org/

10.1055/s-0040-1713592. ISSN 0103-5355.
Copyright $\odot 2020$ by Thieme Revinter

Publicações Ltda, Rio de Janeiro, Brazil
License terms

()ㅇㅇ $\Theta \circledast$ 
him years later to be recognized worldwide for having contributed to so many surgical techniques. After his board graduation in 1865, Kocher spent a year visiting and studying at other European universities; Langenbeck and Virchow in Berlin, Billroth in Vienna, Lister in Edinburgh, and Pasteur and Verneuil in Paris. Upon his return to Vienna, he became Lucke's assistant and in the same year became a Professor. In 1872 Kocher assumed the chair of Surgery at the University of Bern, and began 45 years of continuous, persistent surgery-focused work; he literally established a new school of surgery.

Kocher was also a member of the German Society of Surgery, and was elected President of that Society in 1902. In 1908 he was elected the first President of the International Society of Surgery and in the following year, in 1909, was awarded the highest possible honor, the Nobel Prize of Medicine and Physiology in recognition for his work on the thyroid gland. He has been invited to take up numerous positions at various European Universities, but has always refused to leave Berne. Kocher was a reserved, religious man who devoted himself to tennis and painting in his free time. On his seventieth birthday, he declined from any public demonstration by the University. While Horsley was a surgeon and politician, Virchow was a pathologist, anthropologist and a political dynamo, Kocher was devoted to surgery and surgery alone. Kocher is also considered one of the precursors in organ transplants, as he tried in 1883 to implant human thyroid tissue in patients undergoing total thyroidectomy. World War I disrupted Kocher's international contacts, and his writing in German also contained recognition of his achievements soon after the War.

\section{Kocher and the General Surgery}

Kocher's anatomical knowledge has defined a new surgical technique that has become a model for thyroid surgery, reducing mortality levels from $18 \%$ to $1 \%$, percentages that are still difficult to overcome. Bern became the Mecca for patients with thyroid disorders who came from every corner of the planet. Kocher has performed over 9,000 thyroid surgeries. He was the first surgeon to emphasize the importance of hematological changes and coagulation time as a means of early diagnosis and prognosis in both hypo and hyperthyroidism.

Knowing the experiences of McDowell and Lawson Tait, he was one of the first surgeons to successfully perform gynecological techniques such as ovariotomy, hysterectomy, and aseptic hysteropexy as currently employed.

Maintaining good scientific and surgical relationships with Billroth, Kocher has contributed significantly to making gastrointestinal surgery a science. He created different suture points for bowel loops, duodenum mobilization methods after pyloric resection, contributed to rectal cancer resection methods known today as the Kraske method (1897), as well as simplified surgery for inguinal hernia.

For him, teaching was a science and an art. The history and clinical examination of the patient performed by him was unsurpassed. For him, exploratory surgery was the equivalent of a misdiagnosis.
His lectures and publications were always based on his personal experience and touch. He published his first book "Texbook of Operative Surgery" ${ }^{1}$ in 1892, which had five editions and was a great success; Undoubtedly, the first was the most striking, because it was written with Kocher's dedication and personality only.

\section{Kocher and Trauma}

Kocher's name is often associated with his method of reducing acromioclavicular joint dislocations. The method was demonstrated at the Billroth Clinic in 1870, at a time before radiology. His knowledge of fractures and hemorrhages contributed to his rapid rise in the military career as well. In 1866 he was Lieutenant of the Swiss Army; during the Franco-Prussian War (1870) he taught other colleagues in rescue techniques. He became First Lieutenant at this time. By 1875 he was a colonel and in 1877 he became chairman of the Military Pension Commission, a position he held until his death. With such involvement, it is natural that he was interested in the effects of gunshot wounds and bleeding, increasing the surgical time for meticulous hemostasis. Kocher also spent considerable time understanding firearm and ballistic wounds. Fackler and Dougherty ${ }^{2}$ published an excellent text on the subject.

\section{Kocher and the Genitourinary Tract Surgery}

In 1874 Kocher wrote the chapter "The Testicle and its Tunic, the Epididymis, the Cord, and the Seminal Vesicles in Billroth's Surgery Book, Textbook of General and Special Surgery" The chapter was considered a masterful description of the subject, and 13 years later Kocher published an even more elaborate review in "Deustche Chirurgie" under the title "Male Genital Organ Diseases."

\section{Kocher and Neurosurgery}

The use of meticulous hemostasis (Kocher clamping), intravenous saline application based on animal experiments by Kronecker, Bern physiologist, were also adopted by an American surgeon who became friends with Kocher, William Halsted of John Hopkins., and shortly thereafter by George Crile.

Kocher published the first complete graphics or drawings of human dermatomes (1896). He also wrote a monograph on brain surgery (1901) using experiments on intracranial pressure performed in Bern by a Halsted collaborator, Harvey Cushing, who was also very interested in Kocher's measures of asepsis, hemostasis and intraoperative control.

Hildebrandt et $\mathrm{al}^{3}$ listed Kocher's contributions in chronological order:

1879: About nerve traction in trigeminal neuralgia.

This year, Kocher published his experience in two patients with trigeminal neuralgia. ${ }^{4}$ The treatment consisted in traction of the exposed peripheral branches of the trigeminal in the pain region. In both cases, there was complete reduction of pain.

1880: Specific surgery of the head and the face

A. Vogel ${ }^{5}$ described manually in a notebook a course during the summer of 1880 by Kocher, where he lectured on soft tissue trauma to the head, head fractures including skull base 
fractures, cranial suture diastases, and comminuted fractures. He discussed causes of brain compression and described the clinical signs of intracranial hypertension. He also commented on "brain commotion" and "brain bruise."

1881: London

Kocher attends the 5th International Medical Congress in London $^{6}$ David Ferrier ${ }^{7}$ (1843-1928) presented a hemiparetic monkey after a precise ablation of the motor cortex. The contributions of that event first defined a rational consensus on the function and organization of the human brain, based on participants such as William Osler (1849-1919), John Jackson (1835-1911), William Keen (1837-1932), William MacEwen (1848-1924), Rickman Godlee (1849-1925), Victor Horsley (1857-1916), Joseph Lister (1827-1912), Rudolph Virchow (1821-1902), and Louis Pasteur (1822-1895) among others, emphasizing the idea of creating a universal map of the human cerebral cortex. The period of philosophical speculation in neuroanatomic publications was over, and Kocher actively participated in this historical moment.

\section{Kocher and the Craniometer}

After the 1881 Congress, various instruments were developed to aid the pre-surgical location of the cranio-cerebral topography. These instruments were given different names according to the country, such as Wilson's cirtometer, Kroenlein's cephalometer and Kohler, Broca's craniograph; They all had the same purpose: to allow the target to be located three-dimensionally from the external characteristics of the skull. And of course, they all had limitations. In 1889, Kocher read a thesis described by Ludwig August Müller, and he then came to the realization that target location faults were related to the effect of different cranial shapes. Müller suggested including numerical coefficients in the metal handles, and Kocher also introduced movable handles, explaining in his 1911 compendium, Textbook of Operative Surgery, that the 60-degree anterior motion allowed the exact location of the structures of the region prior to the pre-central gyrus, and the posterior rotation of 60 degrees allowed to limit the borders between the temporal and occipital lobes (-Figs. 1-7). The device was also cited by Quervain, Krause and Cushing, among others. Krause ${ }^{8}$ used it and gave detailed information about its use in his book "Surgery of the Brain and Spinal Cord"; Cushing devoted 6 pages on craniocerebral localization in his chapter "Surgery of the Head" written for Keen's compendium, “Surgery.” Therefore, Kocher ${ }^{9}$ invented a craniometer that became one of the first popular objects of neurosurgical navigation.

1887: Cafe Roth, Bern

Kocher presented an epileptic patient treated for eight years, who had undergone various surgical procedures. Kocher performed a craniotomy on the left occipital lobe, finding and resecting a $2 \mathrm{~cm}$-diameter brain tumor. Pathological evaluation by Langhans revealed "bone tissue" within the tumor. The presentation protocol does not mention the patient's clinical course.

1892: Surgical Texbook

In his first compendium, Kocher ${ }^{1}$ describes soft tissue surgery of the head, the relationship of the gyrus with the skull, and the 23-page trepanning technique, the 15-page viscerocranium surgery, and showed and cited the technique described by Wagner, ${ }^{10}$ temporary cranial resection, later referred to as osteoplastic trepanation (craniotomy). In this compendium, he also emphasized the need to anatomically distinguish motor sensory functions using requested figures manually drawn by Victor Horsley.

1896: Spinal cord injuries in spinal trauma

Kocher ${ }^{11}$ described his experience in diagnosing and treating trauma and spinal disease on 245 pages, with data derived from 78 patients in his clinic. He even proposed a classification of the lesions in 1. Partial (contusion and distortion of the vertebral body) 2 . Isolated fractures of the vertebral arch and spinous process, 3. Isolated dislocation of the articular facets, 4. Isolated fractures of the vertebral body and 5. Traumatic total dislocation. He stressed the relevance of spinal contusion in the genesis of hematomyelia and valued the decompression laminectomy technique. This experience and perhaps the accumulated experience of the Franco Prussian War led him to publish what Hildebrand ${ }^{3}$ regarded as Kocher's greatest contribution to neurology and neurosurgery, which was the first figurative correlation of dermatomes ever published (-Fig. 6 page 1111 of reference ${ }^{3}$ ). In 1917, in his last year of life, Kocher considered the sterile injection of a platelet concentrate (named coagulum) into spinal cord injuries.

1899: About the surgical cure of epilepsy

Kocher firmly believed that the genesis of epilepsy was intracranial hypertension, and that cure could be achieved through dural cleavage or permanent subcutaneous cerebrospinal fluid drainage. In 1896 Hayazo Ito of the University of Tokyo stayed in Bern developing experimental models in epilepsy. His publication contained over 420 references, and when he returned to Japan, he performed several dozen epileptic surgeries. Kocher described his experience in 175 patients at the 28th German Congress of Surgery in Berlin in April 1899. Due to the weight of his name's authority, he initially had many followers, but was confronted in 1910 by Krause and others during the 39th German Congress with several reports of unsatisfactory results through the technique proposed by him. In fact, by 1901 Bier $^{12}$ had already shown that intracranial hypertension was a concomitant sign of epilepsy, but not the causative factor. Surbeck ${ }^{13}$ reports in detail Kocher's relationship with epilepsy.

1900: Kocher, Hayazo Ito and Harvey Cushing in Bern ${ }^{14}$

Ito was the first Professor of the Second Surgical Department at Kyoto University, Japan, from 1900 to 1924 . He remained for 3 years as a research fellow with Kocher and engaged in experimental studies on the relationship between intracranial hypertension and epilepsy, object of interest to Kocher. Ito demonstrated in his experimental studies that saline-induced intracranial hypertension caused a disturbance in blood pressure, translated as "strong and high pulsations" that could be recorded on a kimograph. During his time in Japan, Ito performed 182 Kocher surgeries for epilepsy.

Harvey Cushing worked with Halsted at John Hopkins in Baltimore. Halsted was enthusiastic about the European methodology of university research and suggested to Cushing to spend a year visiting some European centers. Cushing 
visited Bern one year after Ito's departure and stayed for 5 months, conducting an intensive study on intracranial hypertension as a suggestion of Kocher. ${ }^{14}$ Next, Cushing stayed for 4 weeks in Turin at Angelo Mosso's ${ }^{15}$ laboratory. An important event is the fact that Cushing became acquainted in Pavia with the Riva-Rocci device, which was one of the first sphygmomanometers in existence. Cushing then returned to Bern where he stayed another 4 weeks to complete his work, and it is presumed that he carried a sphygmomanometer with him. ${ }^{14}$

Cushing himself describes in one of his monographies (date of 1926) his relationship with Kocher and his influence: "My own interest in the dynamics of the intracranial chamber was first aroused while engaged 25 years ago in the Hallerianum in Berne on a problem suggested by the late Theodor Kocher, who was preparing a monograph on cerebral compression for Nothnagel's Speziellle Pathologie, wherein he laid much more stress on the results of my research during that happy year than they might otherwise have deserved. Cushing returned to Baltimore and founded the Neurosurgery Department at John Hopkins in 1901, taking with him Kronecker and Kocher's fundamentals of volume replacement, asepsis (Lister), and meticulous hemostasis.

1901 In the same year, Kocher published his experience, knowledge, and theories on the anatomy and physiology of cerebral perfusion and various surgical procedures. The monograph was published as the 9th volume of the Spezielle Pathologie und Therapie series and consisted of 457 pages, with $\mathrm{H}$. Nothnagel as editor. ${ }^{16}$ Giving credit to visiting physicians, Cushing and Ito, Kocher made his considerations on the pathophysiology of hypertension. taking into account Cushing's observations of what would later be Cushing's reflex. ${ }^{17}$ In addition to theoretical considerations, Kocher addressed the issue from a surgical standpoint, describing ventricular puncture, artificial respiration, and trepanation methods in the early stages of intracranial hypertension in detail. On 69 pages, he described the indications for trepanations and the different methods existing at the time. ${ }^{16}$

1909: Kocher and the Hypophysectomy

Kocher performed his first hypophysectomy in $1909,{ }^{18}$ joining an elite at the time of only 5 surgeons who had performed this procedure at a time when patients with pituitary tumors were treated with medieval remedies such as eye compresses, alcohol, "stay for four weeks in a dark room". Radiology was in its infancy, there were no hormonal laboratory studies, no diathermy, aspiration (suction), microscope, or antibiotics. Kocher's publications ${ }^{18}$ show how meticulously he and his team prepared this surgery. They studied the literature available at the time, following the publication of Schloffer, ${ }^{19}$ who performed the first transnasal approach to the pituitary, developed specula and other instruments before the procedure was performed, ${ }^{2}$ and were at the forefront of the pathophysiology of pituitary problems certainly influencing Harvey Cushing $^{20}$ to elucidate the cause of acromegaly and other conditions of pituitary function. Cushing performed his first transnasal approach two months after Kocher and recognized and adopted Kocher's approach because of its better cosmetic outcome.
1909 In the same year, Emil Theodor Kocher was the first surgeon in history to receive the Nobel Prize in Physiology and Medicine for his achievements in the fields of physiology, pathology and surgical treatment of the thyroid gland.

Kocher has always been a general surgeon, a visionary, and despite the large amount of accumulated and published information (249 articles and books), curiously he has never had followers or students who dedicated themselves to neurosurgery. ${ }^{1,2,21}$ In 1921, a book in his honor was published with more than 1,000 pages. ${ }^{22}$ The book contained 35 contributions from his former collaborators and colleagues, and there was only one contribution with anatomopathological reference in the neurosurgical field. It took another two decades for Hugo Krayenbühl to create Switzerland's first neurosurgery department in Zurich.

Theodor Kocher was a pioneer in many ways, a visionary who kept his mind open for new knowledge and techniques until the end of his life.

\section{Conflict of Interests}

The authors have no conflict of interests to declare.

\section{References}

1 Kocher T. Chirurgishe Operationslehre. Jena: Fischer; 1892

2 Fackler ML, Dougherty PJ. Theodor Kocher and the scientific foundation of wound ballistics. Surg Gynecol Obstet 1991;172 (02):153-160

3 Hildebrandt G, Surbeck W, Stienen MN. Emil Theodor Kocher: the first Swiss neurosurgeon. Acta Neurochir (Wien) 2012;154(06): 1105-1115, discussion 1115

4 Kocher T. Ueber Nervendehnung bei Trigeminus-Neuralgie Correspondenz-Blat4t für Scchweiz Aerzte; 1879:1-3

5 Vogel A. Spezielle Chirurgie des Gesichts und Kopfes. Vorlesung Prof Dr Kocher, Sommersemester, handschriftliche Aufzeichnung; 1880

6 Unknown. In: MacCormack W, ed. Transactions of the 7 th International Medical Congress, vol 1. London: Kolkmann; 1881

7 Ferrier D. The Functions of the Brain. London: Smith, Elder \& Co; 1876

8 Krause F. Surgery of the Brain and Spinal Cord. vol 1. New York: Rebman; 1921

9 Schültke E. Theodor Kocher's craniometer. Neurosurgery 2009;64 (05):1001-1004, discussion 1004-1005

10 Wagner W. Die temporäre Resektion des Schädeldaches an stelle der Trepanation. Centralbl f Chir 1889;47:833-838

11 Kocher T. Die Läsionen des Rückenmarks bei Verletzungen der Wirbelsäule. Min Grenzgeb Med u Chir 1896;1:482-660

12 Bier A. Über den Einfluss Künstlich erzeugter Hyperämie des Gehins und künstlich erzeugten Hirndrucks auf Epilepsie, Chorea, usw. Grenzgeb Med Chir 1900;7:333-355

13 Surbeck W, Stienen MN, Hildebrandt G. Emil Theodor Kochervalve surgery for epilepsy. Epilepsia 2012;53(12):2099-2103

14 Yonekawa Y, Fandino J. Theodor Kocher, Hayazo Ito, and Harvey Cushing in Berne, Switzerland. Neurol Med Chir (Tokyo) 1998;38 (05):301-303

15 Fulton JF. Harvey Cushing: A bibliography. Springfield: Thomas; 1946:184-192

16 Kocher T. Hirnerschutterung, Hirndruck und chirurgische Eingriffe bei Hirnkraankehelten. Verlag A. HolderWien1901

17 Cushing H. Studies in Intracranial Physiology \& Surgery. London: Oxford University Press; 1926:6

18 Kocher T. Ein Fall von Hypophysis-Tumor mit operative Heilung. Dtsch Z Chirurgia 1909;100:13-37 
Tribute to Theodor Kocher Maset et al.

19 Schloffer H. Erfolgreiche Operation eines Hypophysentumors auf nasalem Wege. Wien Klin Wochenschr 1907;20:621-624

20 Cushing H. The pituitary body and its disorders: Clinical studies produced by disorders of the hypophysis cerebri. Philadelphia: J.B. Lippincott; 1912
21 Gautschi OP, Hildebrandt G. Emil Theodor Kocher (25/8/184127/7/1917)-A Swiss (neuro-)surgeon and Nobel Prize winner. Br J Neurosurg 2009;23(03):234-236

22 Vogel A. Erinnerungssheft für Theodor Kocher. Arch $\mathrm{f}$ klin Chir 1921;150:1 1025 